\title{
SENI: ANTARA BENTUK DAN ISI
}

Widyabakti Sabatari

\section{Pendidikan Tata Busana FT UNY}

\section{Abstract}

When a new art work is created, it usually causes the emergence of new definitions of art, which are based on different points of view and interpretations. Therefore, it is difficult to give an ideal definition of art. The scope of art is so wide and the facet is so various that art has plural meanings. There are always incomplete and incomprehensive views of art. There are also many different branches of art. On account of its wide scope, the philosophy of art is badly needed as a way to comprehend and analyze matters related to art and its definitions.

Based on a view that there is no difference between art and beauty, every beautiful thing is an art and on the contrary something that has the values of art is certainly beautiful. This view causes overlapping descriptions of art meanings. Accordingly, art and beauty often replace each other in the world of art. The question is then about the meaning of art and of beauty, and its forms and shapes.

To create an art work, it is impossible to neglect materials that form it. An art work is physical but the shape itself is not necessarily regarded as art. Whether a physical shape has art values depends on the values inside. These inner values, the so-called art content values, are the first to catch by art appreciators and lovers. In comprehending an art work, the Forms of Fashion Base and the Form and Content in the Fashion Work is applicable to analyse an art's form and conent.

Key words: art, form and content

\section{A. Pendahuluan}

Setiap munculnya karya seni akan melahirkan batasan-batasan seni yang beraneka ragam sesuai dengan cara pandang serta penafsiran yang berbeda-beda pula, sehingga sulit untuk memberikan batasan-batasan seni yang ideal. Seperti pendapat Soedarso Sp. yang mengatakan bahwa seni amat luas cakupannya dan bermacam-macam sekali fasetnya, seperti cerita orang buta yang ingin melihat gajah. Terjadi suatu pandangan orang tentang seni yang tidak lengkap dan tidak menyeluruh (Soedarso, 2005 : 1). Banyak kalangan dari disiplin ilmu yang berbeda yang berusaha memberikan definisi tentang seni, namun karena seni memiliki cakupan yang luas sehingga seni memiliki arti yang jamak.

Begitu luasnya cakupan tentang seni sehingga filsafat seni sangat diperlukan sebagai salah satu piranti untuk memahami dan menelaah halikhwal yang berkaitan dengan seni dan definisinya. Tulisan ini tidak bermaksud untuk menelusuri alur filsafat seni secara terperinci serta mendetail, tetapi akan mensinergikan

Seni: Antara Bentuk dan Isi (Widyabakti Sabatari) 
beberapa contoh pendapat dan pandangan yang diharapkan mampu memberikan klarifikasi terhadap suatu pengertian mengenai "seni, bentuk dan isi" nya.

Begitu banyak definisi tentang seni dari yang paling sederhana sampai dengan definisi yang berusaha menyentuh esensi seni. Sebagaimana yang dikemukakan oleh ahli filsafat dan budaya, bahwa..."seni adalah segala macam keindahan yang diciptakan oleh manusia", maka menurut jalan pikiran ini seni adalah suatu produk keindahan, suatu usaha manusia untuk menciptakan yang indah-indah yang dapat mendatangkan kenikmatan (Soedarso, $1990: 1$ ).

Dalam buku Tinjauan Seni, Ki Hajar Dewantara mengemukakan bahwa seni adalah segala perbuatan manusia yang timbul dari hidup perasaannya yang bersifat indah, hingga dapat menggerakkan jiwa perasaan manusia lainnya. Seni dipandang sebagai sarana komunikasi perasaan manusia. Sedangkan Akhdiat K. Miharja menyebut seni sebagai kegiatan rohani manusia yang merefleksi realitet (kenyataan) dalam suatu karya yang berkat bentuk dan isinya mempunyai daya untuk membangkitkan pengalaman tertentu dalam alam rohani penerimanya. Dalam definisi ini dengan tegas dijelaskan dengan tegas bahwa seni adalah kegiatan rohani, dan bukan semata-mata kegiatan jasmani. Keutuhan suatu ciptaan karya seni sangat ditentukan oleh keterlibatan rohani senimannya dalam berkarya, yang dapat menggetarkan cita rasa baik si pencipta maupun penikmatnya. Sementara itu Thomas Munro berpandangan bahwa seni adala alat buatan manusia untuk menimbulkan efek-efek psikologis atas manusia lain yang melihatnya. Efek tersebut mencakup tanggapan-tanggapan yang berujud pengamatan, pengenalan, imajinasi yang rasional maupun yang emosional Pandangan ini menekankan kegiatan rohani di pihak penerima, seni harus ditanggapi dengan serius dan dengan segenap fungsi jiwa yang ada (Soedarso, $1990: 3-5)$.

Berdasarkan beberapa pandangan ini, dalam kenyataannya dapat dikaitkan dengan seni-seni tradisional yang diciptakan untuk memenuhi rasa indah. Seperti misalnya seni batik yang diciptakan untuk mengungkapkan pikiran dan perasaan manusia ke dalam motif-motif yang indah dan memiliki arti simbolik tertentu, yang dapat menggerakkan hati, memberi semangat hidup dan harapan-harapan bagi si pemakai. Demikian halnya dengan sebuah lagu yang dinyanyikan dengan alunan suara yang merdu, sehingga dapat menyejukkan hati dan perasaan orang yang mendengarnya. Ataupun ukiran-ukiran kayu yang dipasang pada dinding ruang tamu, merupakan hiasan yang menambah semarak pemandangan dan menyenangkan hati bagi yang melihatnya. Akan tetapi menjadi hal yang sanga berbeda apabila dihadapkan pada seni modern yang justru sama sekali tidak indah dan tidak mengenakkan. Sama halnya bila kita membandingkan sebuah lukisan pemandangan yang bercorak naturalistik karya Basoeki Abdullah dengan

Imaji, Vol.4, No.2, Agustus $2006: 238$ - 250 karya Marcel Duchamp yang berjudul "Fountain", benar-benar merupakan suguhan nilai dengan cita rasa yang berbeda dalam penikmatannya.

Bila kita cermati lebih jauh, ada faktor penyebab terjadinya kesenjangan seperti itu. Faktor terdekat yang dimaksud adalah faktor "persepsi", di mana pandangan masyarakat umum yang menganggap bahwa tidak adanya perbedaan antara seni dan keindahan. Segala sesuatu yang indah selalu dianggap seni, demikian pula sebaliknya sesuatu yang memiliki nilai seni pasti indah. Hal ini menyebabkan setiap deskripsi umum terhadap kesenian selalu terjadi tumpang tindih terminologinya. Herbert Read dalam bukunya The Meaning of Art terjemahan Soedarso Sp., menyatakan :

Hampir semua kekeliruan konsepsi kita tentang seni ditimbulkan oleh

kurang ajegnya penggunaan kata-kata seni dan keindahan. Yang jelas

bahwa kedua kata itu selalu salah dalam penggunaannya. Kita selalu beranggapan bahwa semua yang indah adalah seni, atau sebaliknya,

bahwa semua seni itu indah; dan, yang tidak indah bukanlah seni, kejelekan berarti ketiadaan seni (Soedarso, $2000: 3$ ).

Atas dasar pemikiran ini, andaikan seni dan indah harus menempatkan diri pada posisinya masing-masing dalam menyatakan keberadaan suatu karya atau benda seni, kemudian muncul pernyataan apakah yang dimaksud dengan indah atau keindahan itu, dan bagaimanakah bentuk serta wujudnya?.

Mengacu kepada fenomena dan realitas keindahan yang ada serta terlepas dari subyektifitas yang dimiliki, A.A.M. Djelantik menggolongkan definisi keindahan menjadi dua, yaitu keindahan alami atau keindahan yang tidak dibuat oleh manusia serta keindahan yang diciptakan dan diwujudkan oleh manusia. Barang-barang buatan manusia secara umum kita menyebutnya sebagai barang kesenian (Djelantik, 2001 : 1-2). Pemikiran tersebut menegaskan adanya keindahan memiliki ciri atau sifat alamiah, dan keindahan yang berkaitan dengan ciptaan manusia digolongkan dalam karya seni sebagai ciptaan kreatif berdasarkan keahliannya.

Melihat dari sudut pandang yang lain seni dianggap sebagai kemahiran seseorang dalam mengungkapkan perasaan, yang dalam hal ini hasil dari kegiatan itu harus merupakan suatu keutuhan dan kebulatan organis antara unsur yang satu dengan yang lainnya sehingga mencapai kesatuan, seperti dijelaskan The Liang Gie bahwa seni dan hasil karya seni haruslah merupakan suatu kebulatan yang bersifat organis... bahwa dalam suatu bentuk merupakan kesatuan organis, setiap bagian atau unsur memainkan peranan yang tidak hanya dalam rangka dirinya sendiri, melainkan juga dalam rangka semua bagian atau unsur lainnya. Tidak ada bagian yang dapat berdiri sendiri, melainkan harus bersama-sama bagian lainnya yang membentuk kesatuan organis (Liang Gie, 1996 : 18-20).

Seni: Antara Bentuk dan Isi (Widyabakti Sabatari) 
Sebagai hasil penelitiannya dalam bidang ilmu seni, Soedarso Sp. memberikan rumusan sementara terhadap definisi-definisi seni yang ada, seperti yang dinyatakannya sebagai berikut:

Seni adalah segala kegiatan dan hasil karya manusia yang mengutarakan pengalaman batinnya yang karena disajikan secara unik dan menarik memungkinkan timbulnya penga-laman atau kegiatan batin pula pada diri orang lain yang menghayatinya. Hasil karya ini lahirnya bukan karena dido-rong oleh hasrat memenuhi kebutuhan hidup manusia yang paling pokok, melainkan oleh kebutuhan spiritualnya, untuk melengkapi dan menyempurnakan derajat kemanusiaannya. Dengan batasan seperti ini kiranya apa saja yang layak un-tuk disebut seni dapat masuk kedalamnya (Soedarso, 2000: 2).

Berdasarkan kesimpulan tersebut dapat diturunkan suatu pengertian bahwa kata seni termasuk kebutuhan akan seni itu, memiliki konteks yang terpisah dengan kebutuhan manusia yang pokok. Dalam hal ini seni terkadang dianggap suatu kebutuhan yang eksklusif, yang akan ada dan akan dibutuhkan apabila kebutuhan pokok dalam hidup tidak menjadi pemikiran yang utama lagi.

Akhirnya, dari pemaparan oleh beberapa ahli tersebut diperoleh suatu pemahaman bahwa batasan seni yang ideal tidak akan pernah terwujud. Masingmasing memiliki cara tersendiri dalam pengungkapannya yang berbeda satu dengan lainnya.

\section{B. Bentuk dan Isi}

Mendeskripsikan bentuk dan isi suatu obyek adalah bagian kedua dar proses analisis terhadap obyek tersebut. Dalam kaitan ini tentu yang akan dibahas adalah bentuk dan isi suatu karya seni. Untuk mengantisipasi kerancuan yang terjadi dalam pembahasan, terlebih dahulu diuraikan permasalahan yang paling utama menyangkut apa sesungguhnya pengertian bentuk itu dan apa pula yang terkait dengan isi.

Dalam kehidupan sehari-hari selalu dijumpai bermacam-macam benda dengan beraneka ragam bentuk, baik bentuk yang berdimensi dua ataupun bentuk yang berdimensi tiga. Dalam Kamus Besar Bahasa Indonesia, bentuk berarti rupa, wujud. Sedang dalam bahasa Inggris disebut form. Menurut A.A.M. Djelantik bahwa pengertian wujud mengacu pada kenyataan yang nampak secara kongkrit (dapat dipersepsi dengan mata atau telinga) maupun kenyataan yang tidak nampak secara kongkrit (abstrak) yang hanya bisa dibayangkan seperti suatu yang diceriterakan atau dibaca dalam buku (Djelantik, 2001: 17) Selanjutnya dikatakan bahwa dalam seni rupa pemakaian kata wujud, sebagai istilah yang umum untuk semua kenyataan-kenyataan yang terwujud.
Untuk membentuk suatu karya seni tak mungkin lepas dari materi atau bahan yang membentuknya. Dalam hal ini Mudji Sutrisno SJ membedakan istilah materi (matter) dengan material (materials). Material adalah bahan yang digunakan untuk menghasilkan hal-hal yang indrawi, tetapi materi musik adalah suaranya bukan peralatan musiknya, materi puisi adalah suara tertentu dan bukan pembacanya (Sutrisno, 1993: 137). Pandangan ini juga disepakati oleh Jakob Sumardjo yang mengatakan bahwa sebuah benda seni harus memiliki wujud agar dapat diterima secara indrawi (dilihat, didengar, atau didengar dan dilihat) oleh orang lain. Benda seni itu suatu wujud fisik, tetapi wujud fisik itu sendiri tidak serta merta menjadi karya seni. Berseni dan tidaknya suatu wujud fisik ditentukan oleh nilai yang ada di dalamnya (Sumardjo, 2000: 115). Dalam hal ini suatu wujud atau benda dapat disebut bernilai seni apabila ada sikap estetik subyek pengamatnya, karena benda seni itu sendiri mengandung kemampuan untuk merangsang diberikannya nilai oleh subyeknya.

Nilai yang biasa ditemukan dalam karya seni ada dua, yakni nilai bentuk (indrawi) dan nilai isi (dibalik yang indrawi). Nilai bentuk inilah yang pertama-tama ditangkap oleh penerima atau penikmat seni dan serta merta dapat membangkitkan kepuasan dan kegembiraan. Selanjutnya penikmat menangkap perasaan tertentu atau bangkitnya perasaan tertentu oleh bentuk tadi, disini muncul apa yang disebut nilai "isi" seni. Artinya bentuk dapat mengembangkan gagasan dan pesan yang akhirnya diterima oleh penikmat, terjadilah komunikasi nilai seni.

Memahami bentuk dan isi juga sangat dekat dengan gagasan Louis Sullivan, seorang arsitek dari Chicago yang terkenal dengan slogan "Form Follows Function" (bentuk mengikuti fungsi). Merupakan sebuah gagasan yang diterapkan ke dalam seni arsitektur atau pada barang-barang produksi pabrik. Pernyataan yang menjadi sebuah aksioma, sebuah prinsip pertama untuk semua disain modern. Pernyataan ini mengandung maksud bahwa bentuk dan penampilan luar dari setiap barang, di disain mengikuti atau merupakan suatu hasi pengoperasian dari fungsinya. Bertitik tolak dari postulat ini, kita dapat memperoleh hubungan-hubungan nyata : Sesuatu benda seharusnya seperti apa adanya dan sesuai dengan untuk apa bentuk itu dibuat (Feldman, 1991: 267).

Berkait dengan permasalahan di atas, dikemukakan oleh Soedarso Sp. bahwa : Seperti diketahui, dalam rangka menyelamatkan slogan " Form Follows Function" yang terkenal itu Victor memasukkan enam unsur dalam fungsi, yaitu use, need, method, telesis, aestetics, dan association (Soedarso, 2000: 34) Victor Papanek mengemukakan keenam unsur tersebut melalui diagram Kompleksitas Fungsi (Papanek, 1973: 20). 


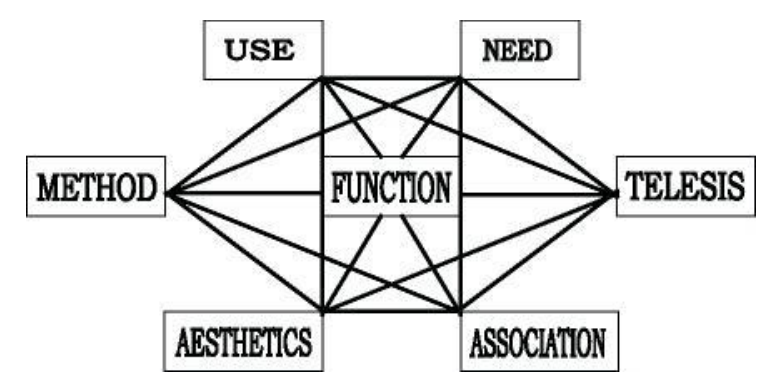

Berdasarkan paparan di atas terlihat bahwa tak mungkin memisahkan antara aspek bentuk dan isi dalam seni. Bentuk seni juga isi seni itu sendiri. Bagaimana bentuknya, begitulah isinya. Tidak ada seniman yang menciptakan sebuah karya seni tanpa kesadaran. Ia menciptakan sebuah benda seni karena ada sesuatu yang ingin disampaikan kepada orang lain, entah perasaannya, suasana hatinya, pemikirannya dan sebagainya, semua dinyatakan lewat bentuk yang sesuai dengan maksud isi hatinya tadi.

\section{Bentuk bentuk Dasar Busana.}

Untuk memahami bentuk dasar busana perlu kiranya penulis ketengahkan terlebih dahulu istilah "bentuk" yang biasa diperounakan dalam tata busana. Bentuk dapat dibedakan menjadi dua, yaitu bentuk bebas dan bentuk geometris. Bentuk bebas adalah bentuk-bentuk yang tidak dapat diukur, seperti : tumbuhtumbuhan, binatang, awan, gelombang laut dan sebagainya. Sedang bentuk geometris seperti : segi empat panjang, segi tiga, kerucut, lengkaran dan silinder (Chodiyah, 1982: 18) Dalam arti yang lain bentuk geometris adalah bentuk-bentuk yang berdasarkan ilmu ukur.

Busana yang dipakai sehari-hari merupakan gabungan dari bermacammacam bentuk, antara lain : bentuk luar dari busana (siluet), bentuk kerung leher, bentuk kerah, bentuk lengan, bentuk rok, bentuk celana, bentuk-bentuk hiasan busana dan pelengkap busana. Bentuk yang terdapat pada busana, dapat bentuk geometris atau pun bentuk bebas.

Untuk memahami " isi " dapat melalui sumber inspirasi atau ide yang terlihat dan tercermin dalam rancangan disain busananya. Beberapa sumber inspiras dalam penciptaan disain busana pada dasarnya dapat di bagi menjadi tiga, yaitu : (1) Sumber Sejarah dan Penduduk Asli; (2) Sumber dari Alam; dan (3) Sumber dar Pakaian Kerja (Kamil, 1986: 30-33). Sumber Sejarah dan Penduduk Asli dapat berupa pakaian nasional penduduk dunia atau pakaian daerah. Sumber dari alam termasuk benda-benda alam seperti aneka tumbuhan, berbagai jenis binatang, gelombang laut dan segala isinya, bentuk-bentuk geometris, dan lain-lain. Sedang sumber dari Pakaian kerja dapat diwujudkan dalam pakaian yang ada hubungannya dengan sport, profesi, jabatan, ataupun tanda-tanda kepangkatan.

Imaji, Vol.4, No.2, Agustus $2006: 238-250$
Intinya apa pun yang ada dalam alam ini dapat dijadikan bumber ide dalam penciptaan disain busana. Syair lagu, peristiwa nasional dan internasional, bahkan kejadian alam yang mengerikan pun dapat menjadi gagasan yang menarik untuk dituangkan dalam karya.

Melalui asal usul busana disebutkan bahwa bentuk awal busana adalah cawat atau celana yang dibuat dari daun atau kulit binatang. Dalam perkembangan selanjutnya bersamaan dengan penemuan bahan-bahan busana yang lain seperti serat linen, wol, kapas, sutra dan lain-lain, muncul bentukbentuk dasar busana yang lain, yaitu celemek panggul, kutang atau tunika, kaftan, ponco dan draperi. Bentuk busana dahulu sangat sederhana yang berbentuk segi empat atau segi empat panjang sesuai kebutuhan. Pelopor penemuan itu adalah bangsa Mesir dan bangsa Babylonia.

Celana telah dipakai oleh manusia pada zaman kuno, mulanya dipakai oleh orang-orang yang tinggal di pegunungan atau orang yamg bepergian dengan menunggang kuda. Penggunaan celana ada yang dijahit dan ada yang tanpa dijahit seperti tampak pada gambar.
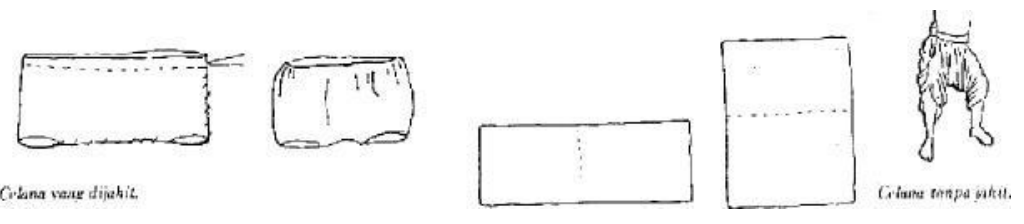

Gambar 1. Bentuk Dasar Celana

Celemek panggul adalah sejenis bentuk dasar busana yang terdiri dari sehelai kain yang berbentuk segi empat. Cara mengenakannya dengan melilitkan satu atau beberapa kali pada tubuh bagian bawah, dari pinggang sampai di sekitar lutut atau sampai menutup mata kaki. Penggunaan celemek panggul ini berbedabeda di beberapa negara. Di Indonesia celemek panggul berupa sarung dan kain panjang.
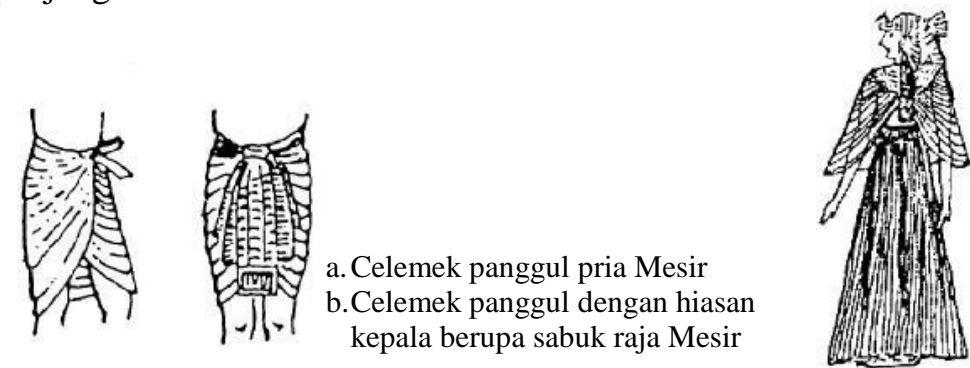

Gambar 2. Bentuk Dasar Celemek Panggul
Celemek wanita Mesir berupa rok Pliss 
Bentuk kutang atau bentuk kemeja disebut juga tunika. Bentuk ini dalam bahasa Inggris disebut robe. Tunika dibuat dari sehelai kain segi empat panjang
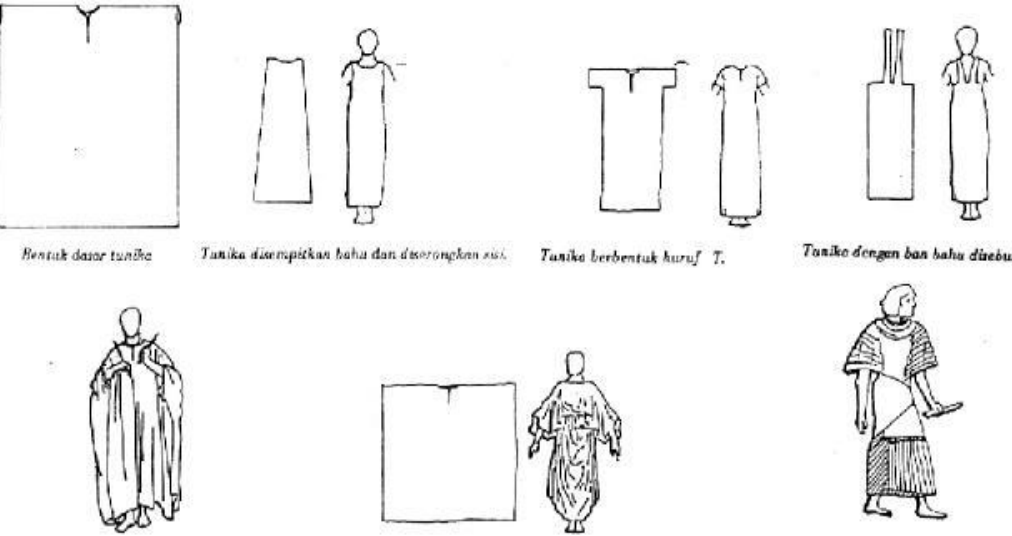

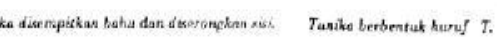

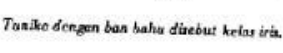

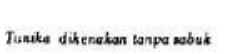

sbak. gerakan tubuh dan me

pengembangan yang na peplos, toga, tebenne dan

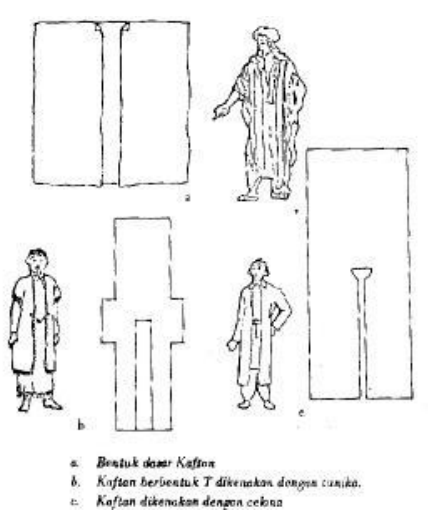

diri. Draperi mengalami a mengenakannya. Ada

Gambar 6. Bentuk Dasar Draperi dan Pengembangannya Keterangan : Gambar 1 sampai dengan 6 diambil dari buku Pengetahuan Pakaian (Roesbani, 1983:22-34).

Bentuk-bentuk dasar busana itu kemudian mengalami perkembangan yang berabad-abad sampai pada bentuk yang kita lihat sekarang ini, dan akan terus berkembang selama manusia masih membutuhkan.

\section{Bentuk dan Isi dalam Karya Busana}

Pada penjelasan terdahulu, bentuk dan sisi dalam karya seni belum dipaparkan secara aplikatif artinya belum diterapkan dalam karya seni tertentu. Berikut ini adalah contoh penerapan bentuk dán tsigyang disampaikan lewat karya busana.

$$
\begin{aligned}
& \text { a. Bentuk daner ponco } \\
& \text { b. Ponco ditenakan lurus }
\end{aligned}
$$

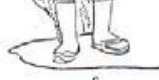

Gambar 7. Bentuk Segi Empat dan Segi Empat Panjang. 
Gambar 8. Bentuk Segi Tiga dan Kerucut
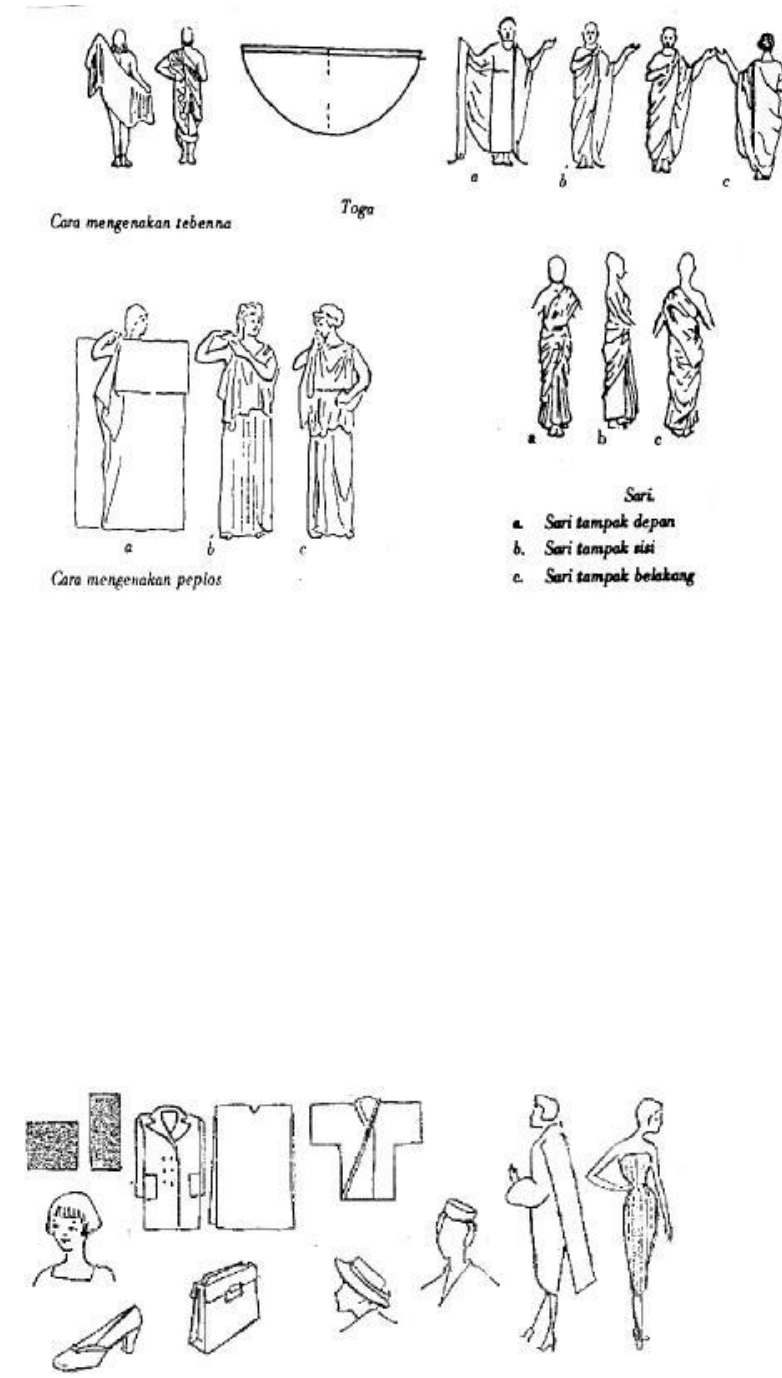

A.A.M. Djelantik, Estetika Sebuah Pentar Masyakakat Seni Pertunjukan Indonesia, Bandung 2001

Bernice G. Chambers MA., Coloun And Design. Prentice Hall Inc., New York, 1951.

Chodiyah dan Wisri A. Mlamdy, Disein Busana, Depdikgud Dirjen Pendasmen, Jakarta, 1982.

Edmund Burke Feldman, "Seni: Ujud dan Gagasan”,Terjemahan Sp. Gustami, Fakultas Seni-Rupa dan Disain ISI, Yogyakarta, 1991.

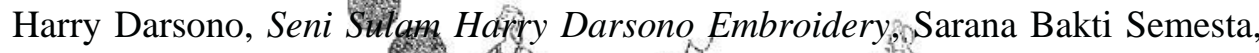
Jakarta, 1992.

Jakob Sumardjo, Filsafatseni TB Bandûng, 2000 . -

Mudji Sutrisno SJ, Eshetika: Filsafan Keindäian Kanisius, Yogyakarta, 1993.

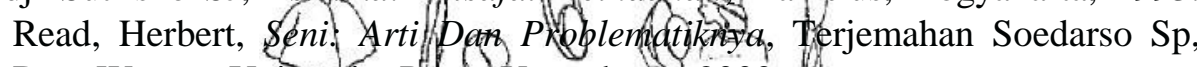
Duta Wacana University Press, Yogyakarta, 2000

Soedarso Sp., Sejarah Perkembangan Seni Rupa Moderen, CV Studio Delapan Puluh Enterprise, Jakarta, Bekerjasama dengan Badan Penerbit ISI Yogyakarta, 2000.

, Tinjauan Seni: Sebuah Pengantar Untuk Apresiasi Seni, Saku Dayar Sana, Yogyakarta, 1990

, Sejarah Perkembangan Seni Rupa Modern, CV. Studio Delapan Puluh Enterprice, Jakarta, Bekerjasama dengan Badan Penerbit ISI Yogyakarta, 2000

"Beberapa Definisi Seni", Bahan Kuliah Teori Seni, Program Pasca Sarjana ISI Yogyakarta, 2004.

"Seni Kriya ISI Yogyakarta Mengantisipasi Masa Depan", Katalog, Pameran Kriya Sen Nopember.

Sri Ardiati Kamil, Fashion D The Liang Gie, Filsafat Se Yogyakarta, 1996

Victor Papanek, Design for Bantam, Random $\mathrm{H}$

Wasia Roesbani dan Roesm Pengadaan Buku Pe

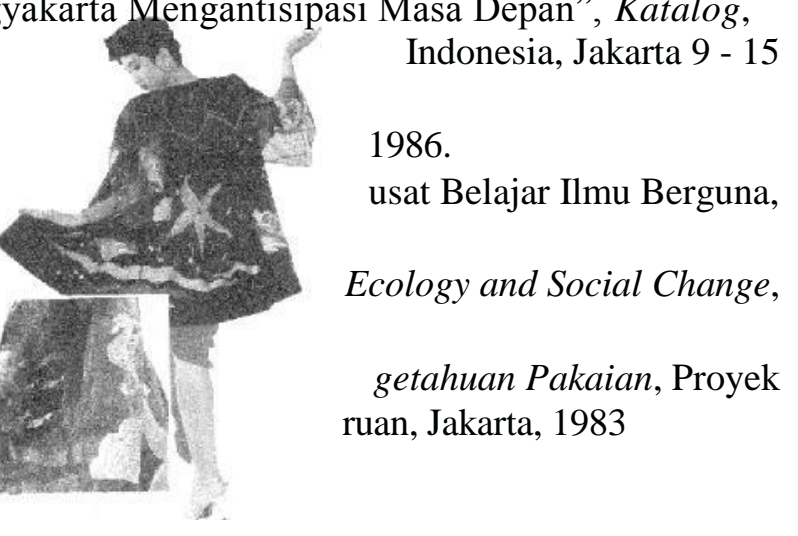




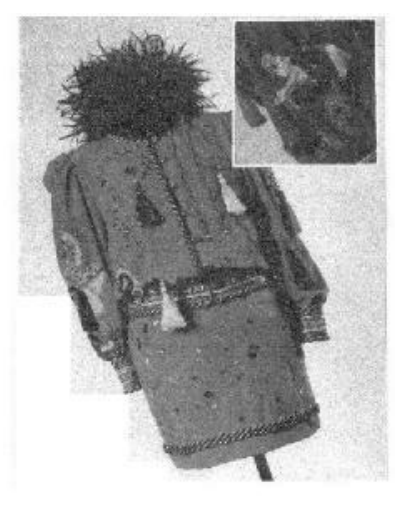

Imaji, Vol.4, No.2, Agustus 2006 : 238 - 250 
